\title{
Effects of Cover Crop Residue and Preplant Herbicide on Early Leaf Spot of Peanut
}

\author{
E. G. Cantonwine, Former Graduate Student, A. K. Culbreath, Professor, and K. L. Stevenson, Associate Profes- \\ sor, Department of Plant Pathology, The University of Georgia Coastal Plain Experiment Station, Tifton 31793-0748
}

\begin{abstract}
Cantonwine, E. G., Culbreath, A. K., and Stevenson, K. L. 2007. Effects of cover crop residue and preplant herbicide on early leaf spot of peanut. Plant Dis. 91:822-827.

Epidemics of early leaf spot, caused by Cercospora arachidicola, of peanut (Arachis hypogaea) are delayed in strip-tilled compared to conventionally tilled fields. This effect may be due to applications of glyphosate used to kill the winter cover crop in strip-tilled fields and/or the presence of cover crop residue at the soil surface of strip-tilled fields. Preplant herbicide (no herbicide, glyphosate, and paraquat), reciprocal residue (plus residue in conventionally tilled plots and minus residue in strip-tilled plots), and added straw mulch were evaluated to determine their effects on early leaf spot epidemics (AUDPC based on incidence and severity, and final percent defoliation) in conventionally tilled and strip-tilled plots. Additional experiments were conducted to characterize the effects of mulch (straw, fumigated straw, and plastic straw [Textraw]) treatments on disease, and to study tillage effects on disease in nonrotated peanut fields. Glyphosate and paraquat had no effect on AUDPC values or defoliation. The addition of straw to conventionally tilled plots significantly reduced disease levels. Cover crop and straw treatments had no significant effect on disease in the strip-tilled plots. AUDPC values were highest in the bare soil plots, lowest in the straw and fumigated straw plots, and intermediate in the plots with Textraw. Fewer initial infections were detected in the Textraw plots compared to the bare soil plots based on results of a trap leaf experiment. Strip-tillage did not consistently suppress early leaf spot epidemics in nonrotated fields. These results show that the presence of cover crop residue is partly responsible for the early leaf spot suppression observed in strip-tilled fields. Cover crop residue may interfere with the dispersal of primary inoculum from overwintering stroma in the soil to the plant tissues.
\end{abstract}

Additional keywords: conservation tillage, crop rotation, disease development, weed control

Under crop rotation, epidemics of early leaf spot, caused by Cercospora arachidicola $\mathrm{S}$. Hori (teleomorph = Mycosphaerella arachidis Deighton), of peanut (Arachis hypogaea L.) are less severe in striptilled fields than in conventionally tilled fields $(13,15)$, with suppression similar to that provided by three applications of chlorothalonil (13). We recently demonstrated that initial disease was lower in strip-tilled plots than in conventionally tilled plots, resulting in an average delay of onset of early leaf spot epidemics by 6 to 12 days (3). This effect appears to be caused by a difference in amount of primary inoculum dispersed to plant tissues from overwintering stroma in the soil rather than differences in host resistance or environment. The primary inoculum of $C$. arachidicola is thought to be dispersed by rain splash, wind, and insects (19).

Corresponding author: A. K. Culbreath

E-mail: spotwilt@uga.edu

Accepted for publication 23 January 2007.

doi:10.1094/PDIS-91-7-0822

(C) 2007 The American Phytopathological Society
Two standard practices associated with strip-tillage that typically are not employed in conventionally tilled fields are preplant applications of the herbicide glyphosate to kill the winter cover crop and maintenance of cover crop residue at the soil surface. Both glyphosate and cover crop residues have been implicated as mechanisms of disease suppression in other pathosystems $(2,6,16)$. Fungicidal activity of glyphosate has been documented for a wide range of fungi, including Pyrenophora triticirepentis and Stagonospora nodorum, pathogens of wheat $(7,18)$, Drechslera teres of barley (20), and Calonectria ilicicola of soybean (2). Berner et al. (2) demonstrated that preplant applications of low rates of glyphosate suppressed red crown rot in soybean fields, which were naturally infested with microsclerotia of C. ilicicola. Although there are no reports of glyphosate toxicity to $C$. arachidicola, negative effects on the germination of $C$. arachidicola conidia were reported for postemergence application rates of lactofen, 2,4-DB, and acifluorfen herbicides, and sporulation of early leaf spot lesions was reduced on plants treated with lactofen and acifluorfen 1 week prior to inoculation with $C$. arachidicola conidia (1). Associations of cover crop residue and disease suppression have been shown in a number of pathosystems, including Phytophthora blight of bell pepper, caused by Phytophthora capsici (16), and two diseases of pumpkin, Plectosporium blight, caused by Plectosporium tabacinum, and black rot, caused by Didymella bryoniae (6). The mechanism of disease suppression by surface residue is thought to be related to reduced rain splash dispersal of inoculum $(9-11,16)$. Addition of straw mulch to bare soil plots resulted in decreased rain splash dispersal of spores of Colletotrichum acutatum, the cause of anthracnose fruit rot of strawberry, and Phytophthora cactorum, the cause of strawberry leather rot, from inoculum sources placed at the soil surface, and decreased foliar disease severities in the field $(9,11)$. A similar effect on splash dispersal and disease was reported for $C$. acutatum in plots with a living sudangrass mulch (14) and for $P$. capsici by a herbicide-treated wheat cover crop (16).

Preliminary observations in the field do not rule out or implicate either glyphosate or cover crop residue as a mechanism of early leaf spot suppression by strip-tillage. Early leaf spot suppression by reduced tillage has been observed where the cover crops in both conservation and conventionally tilled plots were treated with glyphosate (15). However, conventional tillage following application of glyphosate may result in additional inoculum available for dispersal that was not exposed to glyphosate. In addition, suppression of early leaf spot has been observed in strip-tilled plots with low cover crop density due to cattle grazing (12). The objective of this study was to quantitatively measure the effects of cover crop residue and preplant herbicide use on early leaf spot epidemics. In addition, the effect of strip-tillage in fields that were planted to peanut in successive years was evaluated to determine whether early leaf spot disease suppression occurs in fields that are not under crop rotation.

\section{MATERIALS AND METHODS}

Effects of cover crop residue and preplant herbicides. Field studies were carried out in Tifton, GA, at the University of Georgia Coastal Plain Experiment Station Rigdon Farm in 2002 and 2004, and Blackshank Farm in 2003 and 2004. Soil type was a Tifton loamy sand. Fields were planted to cotton (Gossypium hirsutum L.) the preceding year, and peanut 2 years 
prior, grown using conventional tillage. Winter wheat (Triticum aestivum) was planted as a cover crop the previous fall.

Three preplant herbicide treatments were tested in 2002 and 2003, two added straw mulch treatments in 2003 and 2004, and two cover crop residue treatments (reciprocal residue treatments) in all 3 years. Treatments are explained in greater detail below. The experimental trials were designed as randomized complete blocks, with treatments associated with conventional tillage randomly assigned to contiguous plots and those associated with strip-tillage assigned to the remaining plots. In conventionally tilled plots, the winter cover crop was mowed and disked twice prior to deep turning (20 to $25 \mathrm{~cm}$ deep) with a switch plow, and bedded with a disk bedder. In strip-tillage plots, a subsoil shank attached to a two-row strip-till implement (Kelley Manufacturing Co., Tifton, GA) was used to loosen the plow pan $33 \mathrm{~cm}$ beneath the row, while the implement tilled strips approximately 20 to $25 \mathrm{~cm}$ wide. Treatment plot sizes were 1.8 $\times 6.0 \mathrm{~m}$ separated by $2.4-\mathrm{m}$ alleys in 2002 , and $7.2 \times 7.5 \mathrm{~m}$ separated by $3.0-\mathrm{m}$ alleys in 2003 and 2004. The susceptible cultivar Georgia Green was planted to $91-\mathrm{cm}$ spaced single rows on 13 May 2002 and 25 May 2004 at the Rigdon Farm, and 15 May 2003 and 26 May 2004 at the Blackshank Farm. Treatments were replicated three times in 2002, four times in 2003, and four times in each of two fields in 2004.

Preplant herbicide treatments were: (i) glyphosate (Roundup 4 EC, Monsanto, Kansas City, MO) at $1.2 \mathrm{~kg}$ a.i. $\mathrm{ha}^{-1}$; (ii) paraquat (Starfire 1.5, Syngenta Crop Protection, Greensboro, NC) at $0.1 \mathrm{~kg} \mathrm{ha}^{-1}$; and (iii) no herbicide. Paraquat was selected as a preplant herbicide of different chemistry because glyphosate was found to have more fungicidal activity than paraquat against Septoria nodorum of wheat (7) and Drechslera teres in barley straw (20). Herbicide treatments were applied to plots prior to tillage in striptilled plots, and after tillage in conventionally tilled plots. For the no-herbicide treatment, the cover crop residue was killed by mowing and deep turning in conventional tillage, and was allowed to senesce naturally in response to increasing daily mean temperatures in strip-tillage. Weeds in strip-tilled plots not treated with herbicide were removed manually.

Cover crop residue and added mulch treatments (mulch treatments) were: (i) removal of cover crop residue in striptilled plots; (ii) addition of residue from the corresponding strip-tilled plot to the surface of conventionally tilled plots; (iii) addition of one bale per plot of wheat straw mulch to the surface of conventionally tilled plots; and (iv) addition of one bale per plot of wheat straw mulch to the surface of strip-tilled plots. Cover crop residue was removed from strip-tilled plots by cutting near the soil with a string trimmer and raking with minimal disturbance of the soil. The cover crop residue treatments are referred to as "reciprocal residue treatments" when the corresponding striptilled and conventionally tilled treatments are discussed together. Mulch treatments were applied 12 to 14 days after planting (DAP) in all years.

Early leaf spot incidence was assessed weekly, beginning when symptoms first appeared. Disease incidence (the percentage of leaves with one or more lesions or defoliated leaflets) was assessed on leaves of 10 lateral branches arbitrarily collected from each plot beginning 78 DAP in 2002, 59 DAP in 2003, and 56 DAP in 2004. Leaf spot severity per plot was assessed using the Florida 1 to 10 scale rating system, where $1=$ no leaf spot; 2 = very few lesions on the leaves, none on the upper canopy; $3=$ few lesions on the leaves, very few on the upper canopy; $4=$ some lesions with more on the upper canopy, 5\% defoliation; $5=$ lesions noticeable even on upper canopy, $20 \%$ defoliation; $6=$ lesions numerous and very evident on upper canopy, $50 \%$ defoliation; $7=$ lesions numerous on upper canopy, $75 \%$ defoliation; $8=$ upper canopy covered with lesions, $90 \%$ defoliation; 9 = very few leaves remaining and those covered with lesions, $98 \%$ defoliation; and $10=$ plants completely defoliated and killed by leaf spot (5). Severity was assessed weekly for 4 weeks beginning 98 DAP in 2002, and 9 weeks beginning 63 DAP in 2003. In 2004, severity assessments were made at 7- to 22-day intervals six times beginning 56 DAP. Final percent defoliation was estimated from the last severity assessment, 127 DAP in 2002, 119 DAP in 2003, and 131 DAP at the Rigdon Farm and 132 DAP at the Blackshank Farm in 2004. Mean disease incidence and severity of the conventionally tilled control, strip-tilled control, and reciprocal residue treatments were plotted against assessment date for each field and year. Fisher's LSD values were computed for each plotted assessment date using the Proc MIXED procedure of SAS ( $\mathrm{v} 8.3$; SAS Institute, Inc., Cary, NC) to compare disease levels in the conventionally tilled control, strip-tilled control, and reciprocal residue treatments in each year, field, and assessment date.

For each plot, the area under the disease progress curve (AUDPC) was computed for percent incidence and severity (17). Data from 2002 and 2003 were analyzed to assess the effects of tillage and herbicide treatment on AUDPC and final percent defoliation using the Proc MIXED procedure with year and replication as random effects. Data from 2003 and 2004 were similarly analyzed to assess the effects of mulch treatments on AUDPC and final percent defoliation; 2002 data from the reciprocal residue treatments were not included because the added straw mulch treatments were not tested that year. The term "disease intensity" is used when percent incidence and severity are discussed together.

Characterization of disease suppression by straw mulch. Experimental plots, $3.6 \times 7.5 \mathrm{~m}$ with $3.0-\mathrm{m}$ alleys, of the cultivar Georgia Green were planted to $9.1-\mathrm{cm}$ spaced single rows in conventionally tilled fields on 26 May 2003 and 2 June 2004 at the Rigdon Farm. Four treatments, consisting of surface application of one bale per plot of wheat straw mulch, fumigated wheat straw mulch, or synthetic (polypropylene) pine straw mulch (Textraw, Yarn Extrusion Systems, Inc., Thomasville, GA), and bare soil control, were replicated five times. Straw bales were fumigated with $67 \%$ methyl bromide and $33 \%$ chloropicrin at 0.48 to $0.54 \mathrm{~kg} \mathrm{~m}^{-3}$ under plastic for 3 to 4 days. These rates were well above the recommended rate, 0.024 to $0.064 \mathrm{~kg} \mathrm{~m}^{-3}$, due to the volume fumigated, 0.87 to $1.48 \mathrm{~m}^{3}$, being smaller than the potential volume of fumigation of the smallest chemical canister available. The fumigated bales were removed from the plastic immediately before placement in the field. The mean weights of bales were $10.0 \mathrm{~kg}$ for fumigated wheat straw in 2003 , and nonfumigated wheat straw in 2003 and $2004,18.1 \mathrm{~kg}$ for fumigated straw (wheat, corn mix) in 2004, and $13.6 \mathrm{~kg}$ for Textraw both years. Treatments were applied 7 DAP in 2003 and 15 DAP in 2004.

Disease severity was assessed on a 7- to 14-day interval six times throughout the season using the Florida 1 to 10 scale, and AUDPC was computed for each plot. Data were analyzed to assess the effect of straw mulch treatments on AUDPC using the Proc MIXED procedure of SAS with year and replication as random effects.

A trap leaf experiment was carried out to estimate the occurrence and frequency of primary infections in control and Textraw plots to evaluate whether the physical presence of residue at the soil surface contributes to the reduction in the amount of primary infections observed in strip-tilled plots compared to conventionally tilled plots (3). Five first or second newly expanded asymptomatic peanut leaves (trap leaves) per plot were detached at the base of the petiole and placed in test tubes as described by Cantonwine et al. (3). Leaves were transported to the laboratory and incubated in a mist chamber at room temperature $\left(20\right.$ to $\left.23^{\circ} \mathrm{C}\right)$ and a 12 -h photoperiod. After $48 \mathrm{~h}$, misting was discontinued. Water was added to test tubes as needed. After 14 days, the mean number of lesions per leaf and percentage of leaves with lesions (incidence) were recorded. Trap leaves were sampled at 32 DAP and continued weekly until disease was observed on trap leaves collected from at least one plot of both treatments. Data from the final collection dates for each field (73 DAP in 
2003 and 57 DAP in 2004) were analyzed using the Proc MIXED procedure. Relative humidity (RH) and air temperature (AT) within the peanut canopy of one replication each year of Textraw and bare soil plots were measured every $30 \mathrm{~min}$ using HOBO dataloggers (H8 Pro Series, Onset Computer Corporation, Bourne, MA). Seasonal means of RH and AT were computed and compared to determine possible environmental effects of the Textraw treatment.

Effect of tillage treatments in fields without crop rotation. A field study was carried out at the University of Georgia Coastal Plain Experiment Station Lang Farm, Tifton, during the 2002 to 2004 growing seasons. Fields were planted to peanut the previous year in 2003 and 2004, and 2 years prior in 2002. The winter cover crop, planted the previous fall, was winter wheat in 2002, and oat in 2003 and 2004.

Seed of Georgia Green were planted to conventionally tilled and strip-tilled treatment plots on 23 May 2002, 4 June 2003, and 26 May 2004 as described above. No preplant herbicide was applied in the conventionally tilled plots, and glyphosate, 1.2 $\mathrm{kg}$ a.i. $\mathrm{ha}^{-1}$, was applied to all strip-tilled plots. Treatments included conventionally tilled and strip-tilled in all 3 years and the reciprocal cover crop residue treatments (minus residue in strip-tillage and plus residue in conventional tillage), as described previously, in 2003 and 2004. Treatments were replicated four times each year, and plot sizes were $1.8 \times 7.5 \mathrm{~m}$ in 2002, $5.4 \times 12.1 \mathrm{~m}$ in 2003, and $5.4 \times 7.5$ $\mathrm{m}$ in 2004. No fungicides were applied to plots.

Percent incidence of early leaf spot was assessed weekly for 5 weeks beginning 69 DAP in 2002, and 6 weeks beginning 57 DAP in 2004. Leaf spot severity was assessed using the Florida 1 to 10 scale six times beginning 100 DAP in 2002, five times beginning 44 DAP in 2003, and six times beginning 57 DAP in 2004. For each plot, AUDPC was computed for percent incidence and severity separately. Treatment effects on AUDPC values were tested using the PROC MIXED procedure of SAS with year and replication as random effects.

\section{RESULTS}

Effects of cover crop residue and preplant herbicides. Disease progress curves for early leaf spot incidence in the conventionally tilled control (no herbicide), strip- tilled control (glyphosate), and reciprocal residue treatments are shown in Figure 1. Disease progress curves for Florida scale severity ratings of these treatment plots are shown in Figure 2. In most cases, disease intensity (incidence and severity) was higher in the conventionally tilled control plots than in the strip-tilled control plots, and intermediate in the reciprocal residue treatment plots. Based on Fisher's LSD values, disease intensity was significantly higher in the conventionally tilled control plots than in the conventionally tilled plots with added cover crop residue on 85 and 106 DAP (incidence), and 113, 120, and 127 DAP (severity) at the Rigdon Farm in 2002; 59, 73, and 80 DAP (incidence), and 77, 91, 98, and 113 DAP (severity) at the Blackshank Farm in 2003; 63 and 70 DAP (incidence), and 56, 64, 78, 92, and 104 DAP (severity) at the Rigdon Farm in 2004; and on all assessment dates (incidence), and 56, 75, and 110 DAP (severity) at the Blackshank Farm in 2004. Disease intensity was significantly lower in the strip-tilled control plots than in the striptilled plots where the cover crop residue had been removed on 106 and 113 DAP (incidence), and 120 and 127 DAP (severity) at the Rigdon Farm in 2002; on all
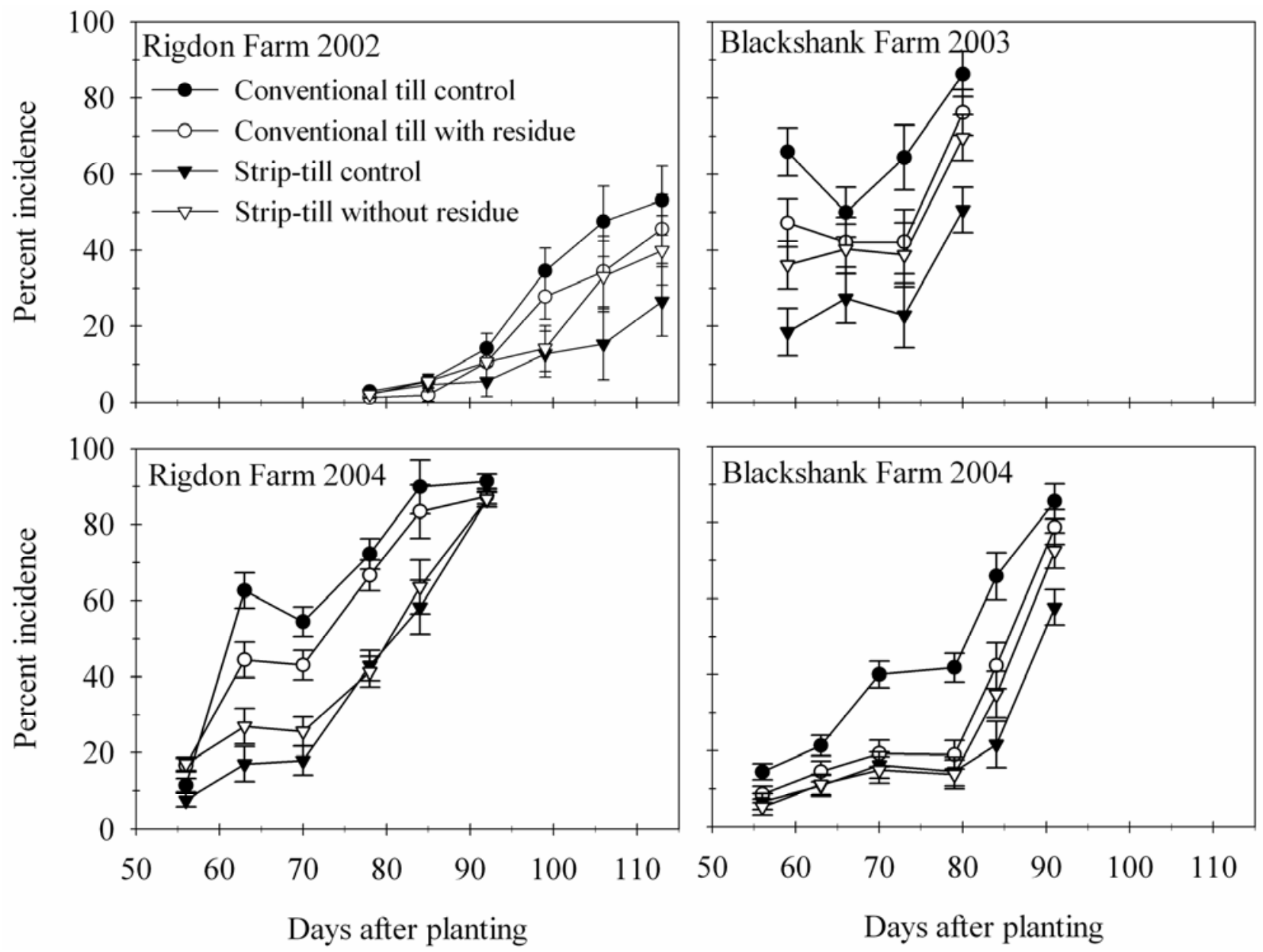

Fig. 1. Progress of early leaf spot incidence over time in peanuts planted in conventionally and strip-tilled plots with or without cover crop residue. Data points are least square means of three replications for the Rigdon Farm in 2002 and four replications for the Blackshank Farm in 2003 and 2004 and Rigdon Farm in 2004. 
assessment dates (incidence), and 98 and 105 DAP (severity) at the Blackshank Farm in 2003; 92 DAP (severity) at the Rigdon Farm in 2004; and 84 and 91 DAP (incidence) at the Blackshank Farm in 2004.

There were no significant interactions among preplant herbicide, tillage, or year; therefore, data were pooled across preplant herbicide treatment and year to test for tillage effects, and across tillage treatment and year to test for preplant herbicide effects. Disease incidence and severity AUDPC values, and final percent defoliation levels, were greater in the conventionally tilled plots than in the strip-tilled plots (Table 1). No significant preplant herbicide effects were observed on disease intensity (Table 1).

In most cases, the mulch treatments in conventionally tilled plots resulted in higher levels of disease than the mulch treatments in strip-tilled plots (Table 2). The one exception occurred when mulch and tillage AUDPC were based on disease incidence. Epidemic intensity, as measured by this variable, in the conventionally tilled plots with added straw mulch was similar to that in the strip-tilled plots where the cover crop residue had been removed, and was statistically comparable to that in the strip-tilled control plot. The addition of cover crop residue to conventionally tilled plots significantly reduced AUDPC incidence and severity values compared to the conventionally tilled control, with the added straw treatment providing more disease suppression than the added cover crop residue treatment based on the incidence AUDPC variable. The addition of straw mulch or removal of cover crop residue in the strip-tilled plots did not affect the disease variables assessed compared to the strip-tilled control. However, AUDPC values were significantly lower in strip-tilled plots with added straw mulch treatment than in those where cover crop residue was removed (Table 2). Final percent defoliation was $\geq 75 \%$ for all

Table 1. Effects of tillage and preplant herbicides on area under the disease progress curve (AUDPC) based on early leaf spot incidence and severity assessments, and final percent defoliation for peanut plots in 2002 and 2003 combined

\begin{tabular}{lccc}
\hline Treatment & $\begin{array}{c}\text { AUDPC } \\
\text { incidence }^{\mathbf{x}}\end{array}$ & $\begin{array}{c}\text { AUDPC } \\
\text { severity }^{\mathbf{y}}\end{array}$ & $\begin{array}{c}\text { Final defoliation } \\
(\%)\end{array}$ \\
\hline Tillage & & & \\
$\quad$ Conventional & 575 & 216 & 86 \\
$\quad$ Strip & 238 & 160 & 55 \\
& $(<0.01)^{\mathrm{z}}$ & $(<0.01)$ & $(<0.01)$ \\
Preplant herbicide & & & 69 \\
$\quad$ No application & 394 & 190 & 71 \\
Glyphosate & 398 & 190 & 71 \\
Paraquat & 427 & 186 & $(0.85)$ \\
& $(0.94)$ & $(0.84)$ & \\
\hline
\end{tabular}

${ }^{\mathrm{x}}$ Least square means from Proc MIXED of AUDPC using the number of leaves with at least one early leaf spot lesion or one defoliated leaflet per total number of leaves of 10 lateral branches $\times 100$.

y Based on Florida 1 to 10 scale.

${ }^{\mathrm{z}}$ The $P$ value in parentheses refers to the treatment comparison immediately above the value.
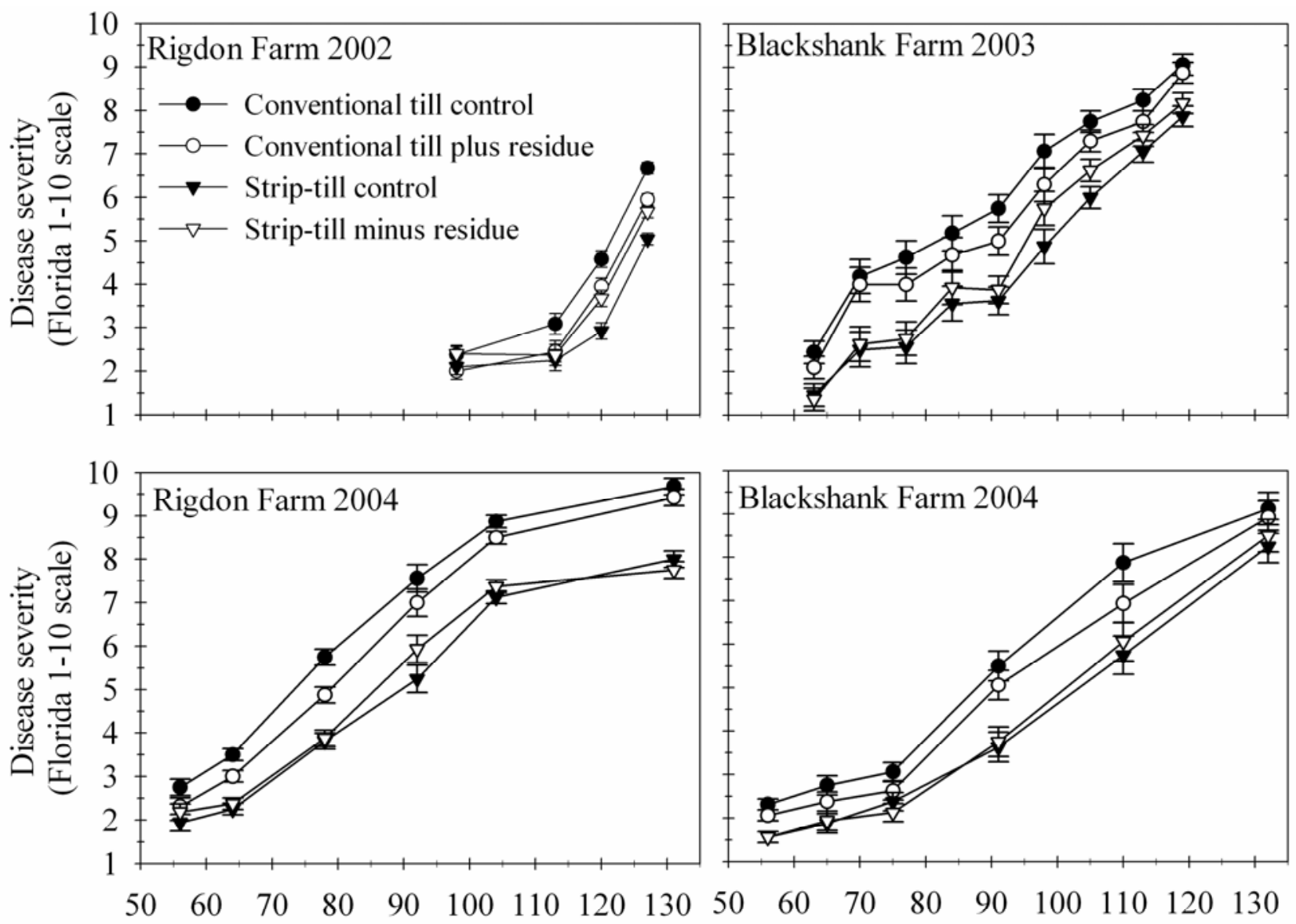

Days after planting

Days after planting

Fig. 2. Progress of early leaf spot severity over time in peanuts planted in conventionally and strip-tilled plots with or without cover crop residue. Data points are least square means of three replications for the Rigdon Farm in 2002 and four replications for the Blackshank Farm in 2003 and 2004 and Rigdon Farm in 2004. 
treatment plots included in the analysis. Mulch treatments within each tillage system did not affect final percent defoliation, but defoliation was significantly greater in the conventionally tilled plots than in the strip-tilled plots.

Characterization of disease suppression by straw mulch. All mulch treatments resulted in significantly lower AUDPC values than the bare soil control $($ AUDPC $=254)(P<0.01)$. AUDPC values in plots treated with straw and fumigated straw mulch were similar, 222 and 224 , respectively, and were significantly lower than in plots treated with Textraw, $238(P<0.01)(\mathrm{LSD}=8, \mathrm{df}=27)$.

Trap leaves from the control and Textraw plots indicated a lower incidence of initial infections in the Textraw than control treatment, 0.46 and $0.88 \%$ incidence, respectively $(P<0.01)$, and fewer initial infections, 2.0 and 6.6 lesions per leaf, respectively $(P<0.01)$. Seasonal means of $\mathrm{RH}$ and AT within the peanut canopy were similar in the Textraw and the bare soil plots (data not shown).

Effects of tillage treatments in fields without crop rotation. In 2002, neither AUDPC based on disease incidence nor severity was significantly different in conventionally or strip-tilled plots $(P \geq 0.17)$ (Table 3). Likewise, no difference in
AUDPC was detected among tillageresidue treatments in $2003(P=0.99)$. In 2004, AUDPC based on incidence assessments was lower in the strip-tilled plots and the conventionally tilled plus residue plots than in the conventional tillage control plots $(P \leq 0.02)$, while AUDPC based on severity ratings was lower in the striptilled plots than in the conventionally tilled plots $(P<0.01)$ (Table 3$)$.

\section{DISCUSSION}

Based on our results, preplant application of herbicide is not the cause of early leaf spot suppression in strip-tillage. None of the disease variables assessed were affected by either glyphosate or paraquat treatments. The lack of consistent leaf spot suppression in the continuous peanut tests also provides evidence that glyphosate was not the primary factor in leaf spot suppression because all strip tillage treatments in those tests included use of glyphosate.

The presence of cover crop residue at the soil surface is involved in disease suppression. Early leaf spot epidemics were less severe in conventionally tilled plots when cover crop residue or straw mulch was added to the soil surface compared to the bare soil control plots, and there was significantly less disease in the strip-tilled plots where straw mulch had been added to

Table 2. Effects of mulch treatments on area under the disease progress curve (AUDPC) based on incidence and severity assessments, and final percent defoliation for peanut plots in 2003 and 2004 combined

\begin{tabular}{|c|c|c|c|}
\hline Treatment & $\begin{array}{c}\text { AUDPC } \\
\text { incidence }^{\mathrm{x}, \mathrm{y}}\end{array}$ & $\begin{array}{c}\text { AUDPC } \\
\text { severity }^{y, z}\end{array}$ & $\begin{array}{c}\text { Final } \\
\text { defoliation } \\
(\%)^{y}\end{array}$ \\
\hline Conventional tillage control & $1,773 \mathrm{a}$ & $410 \mathrm{a}$ & $97 \mathrm{a}$ \\
\hline Conventional tillage plus cover crop residue & $1,378 \mathrm{~b}$ & $375 \mathrm{~b}$ & $96 \mathrm{a}$ \\
\hline Conventional tillage plus straw & $1,098 \mathrm{c}$ & $360 \mathrm{~b}$ & $97 \mathrm{a}$ \\
\hline Strip-tillage control & $877 \mathrm{~cd}$ & $299 \mathrm{~cd}$ & $89 \mathrm{~b}$ \\
\hline Strip-tillage minus cover crop residue & $1,091 \mathrm{c}$ & $312 \mathrm{c}$ & $90 \mathrm{~b}$ \\
\hline Strip-tillage plus straw & $657 \mathrm{~d}$ & $280 \mathrm{~d}$ & $90 \mathrm{~b}$ \\
\hline$P$ value & $<0.01$ & $<0.01$ & $<0.01$ \\
\hline $\operatorname{LSD}(P=0.05)$ & 242 & 25 & 3 \\
\hline
\end{tabular}

${ }^{\mathrm{x}}$ Least square means from Proc MIXED of AUDPC using the number of leaves with at least one early leaf spot lesion or one defoliated leaflet per total number of leaves of 10 lateral branches $\times 100$.

${ }^{y}$ Means within a column followed by the same letter do not differ at $P=0.05$ according to Fisher's test for least significant difference (LSD).

${ }^{\mathrm{z}}$ Based on Florida 1 to 10 scale.

Table 3. Effects of tillage and reciprocal cover crop residue treatments on area under the disease progress curve (AUDPC) for early leaf spot in continuous peanut fields, 2002 to 2004

\begin{tabular}{|c|c|c|c|c|c|}
\hline \multirow[b]{2}{*}{ Treatment } & \multicolumn{2}{|c|}{2002} & \multirow{2}{*}{$\begin{array}{c}\mathbf{2 0 0 3}^{\mathrm{x}} \\
\text { Severity } \\
\text { AUDPC }\end{array}$} & \multicolumn{2}{|c|}{$2004^{x}$} \\
\hline & $\begin{array}{l}\text { Incidence } \\
\text { AUDPC }^{\mathrm{x}}\end{array}$ & $\begin{array}{l}\text { Severity } \\
\text { AUDPC }^{y}\end{array}$ & & $\begin{array}{l}\text { Incidence } \\
\text { AUDPC }^{\mathrm{x}}\end{array}$ & $\begin{array}{l}\text { Severity } \\
\text { AUDPC }^{y}\end{array}$ \\
\hline Conventional tillage & 371 & 207 & 233 & 1658 & 277 \\
\hline $\begin{array}{l}\text { Conventional tillage plus } \\
\text { cover crop residue }\end{array}$ & & & 232 & 1281 & 253 \\
\hline Strip-tillage & 897 & 241 & 233 & 999 & 208 \\
\hline $\begin{array}{l}\text { Strip-tillage minus cover } \\
\text { crop residue }\end{array}$ & & & 233 & 1246 & 215 \\
\hline $\operatorname{LSD}(P=0.05)$ & $\mathrm{NS}^{\mathrm{z}}$ & NS & NS & 194 & 16 \\
\hline
\end{tabular}

${ }^{\mathrm{x}}$ Least square means from Proc MIXED of AUDPC using the number of leaves with at least one early leaf spot lesion or one defoliated leaflet per total number of leaves of 10 lateral branches $\times 100$.

${ }^{y}$ Based on Florida 1 to 10 scale.

${ }^{\mathrm{z}}$ Not significant. the soil surface compared to the plots where the cover crop residue had been removed. These effects were not evident at the end of the epidemic, with final percent defoliation comparable among the treatments in each tillage system. However, early leaf spot pressure was high in these fields (final defoliation $\geq 89 \%$ across experiments), and it is possible that end-ofseason defoliation would have remained significantly lower in these plots if disease pressures had not been so great. At the Rigdon Farm in 2002, which was excluded from the mulch treatment analyses because the added straw mulch treatment was not tested in that experiment, disease intensity was relatively low, and final percent defoliation was different for the reciprocal residue treatments compared to their corresponding tillage treatments. It is possible that in fields or seasons with low disease pressure, the application of mulch would provide sufficient disease suppression through the entire season. Similar interactions between treatment and disease pressure have been observed for other factors that affect early leaf spot. For example, peanut genotypes with varying levels of disease resistance to early leaf spot had comparable final percent defoliation in fields where disease pressure was high, and significantly different final defoliation percentages in fields where disease pressure was low (4). It is important to note that in most cases the disease suppression resulting from the addition of cover crop residue or straw mulch to conventionally tilled plots was not as great as the disease suppression observed in the strip-tilled control plots with or without cover crop residue. This suggests that the presence of cover crop residue at the soil surface is not the only disease suppressive factor of striptillage, and that tillage differences that were not explored in these experiments also may affect disease.

Early leaf spot suppression was similar in plots with added straw and fumigated straw mulch. Because the fumigation of straw did not affect disease suppression, it appears that microorganisms associated with wheat straw are not critical for suppression. However, this does not rule out a biological component of suppression because fumigated straw can be colonized and degraded by microorganisms. Disease suppression also was observed for Textraw mulch plots compared to bare soil plots, although suppression was lower than in the straw mulch treatments. The observation of less disease in the Textraw plots compared to the bare soil plots and of fewer initial infections in the Textraw plots based on the trap leaf experiment suggests that some of the early leaf spot suppression that occurs with the presence of straw mulch in conventionally tilled plots can be explained by the physical presence of mulch at the soil surface. A previous field study demonstrated that estimates of initial in- 
fections of $C$. arachidicola in peanut by trap leaves could be attributed to differences in the ability of the pathogen to cause infections rather than differences in environmental conditions or host resistance (3). There was no indication that environmental conditions differed between the Textraw mulch and bare soil plots; therefore, it is likely that the fewer initial infections that were observed in the Textraw plots by the trap leaves and the overall suppression of early leaf spot AUDPC values were due to fewer conidia dispersed to these leaves in the field. Because Textraw is made of an inert material (polypropylene), it is likely that dispersal of initial inoculum from the soil was restricted by its presence at the soil surface. The inert nature of the Textraw material would not be expected to affect production of conidia on overwintering debris in the soil either by competition with other microorganisms or allelopathy.

The mechanism of early leaf spot suppression by mulch may be similar to that reported for leather rot and anthracnose fruit rot of strawberry, where the horizontal dispersal of spores by rain splash had a steeper gradient for plots with straw mulch at the soil surface than plots with bare soil (9-11). A rain simulation study in peanut plots under strip-tillage and conventional tillage indicated that rain-drop-induced splash sediment was 2.5 times lower $(P<$ 0.01 ) in the strip-tilled plots (C. C. Truman, personal communication). Suppression of spore dispersal by surface mulch has been suggested to be related to its effect on increasing surface roughness, which has been shown to reduce rain splash velocities and alter the angle of splash trajectories $(9,10,22)$. Splash dispersal of $C$. acutatum conidia was found to be greater in plots with plastic sheet mulch than with bare soil or straw mulch (23), and it is possible that the physical characteristics of the Textraw mulch, although providing similar complexity to surface roughness as the organic mulches, did not reduce rain splash dynamics as well as the organic mulch. This may explain why a greater level of disease suppression was observed with the organic mulches compared to the plastic mulch. It also is possible that the organic mulches enhanced microorganism composition near the soil surface (8) or released chemical toxins (21) that interfered with inoculum production of overwintering fungal stroma.

Without crop rotation of at least 1 year, growers should not rely on strip-tillage to help manage early leaf spot because no suppression was observed with strip-tillage in 2 of the 3 years tested in fields planted to peanut the preceding summer. Overall, the presence or absence of cover crop residue did not appear to have a strong effect either year tested. However, in 2004, disease development in the residue treatments showed numerical trends that corresponded with those seen in the cover crop residue study. It was surprising that early leaf spot epidemics were not more severe in strip-tilled plots than in conventionally tilled plots without rotation; a number of volunteer peanut plants were present in strip-tilled plots shortly after planting each year, and we expected infested peanut debris from the previous season to be nearer to the soil surface in the strip-tilled plots than in the conventionally tilled plots. It is possible that much of the infested peanut debris was buried in strip-tilled plots during inversion in the previous year or during planting of the cover crop the previous fall, which may have resulted in similar amounts of debris with and without extensive tillage. It also is possible that the inoculum load near the soil surface was greater in the strip-tilled plots than in conventionally tilled plots, but that the suppressive effect of striptillage resulted in comparable disease levels between the tillage systems in 2 of 3 years tested.

In conclusion, application of a pretillage herbicide is not the cause of documented leaf spot suppression by strip-tillage, while the maintenance of cover crop residue at the soil surface appears to explain part of the suppression. Cover crop residue likely interferes with the dispersal of initial inoculum from overwintering stroma in the soil to the plant tissues. Density of the cover crop may influence the suppression potential of strip-tillage; however, more research is needed to characterize this relationship. Without crop rotation of at least 1 year, growers should not rely on strip-tillage to help manage early leaf spot epidemics. Additional research is needed to identify the mechanism of initial inoculum suppression by surface mulch, and to identify other factors of strip-tillage involved in suppression of early leaf spot of peanut.

\section{ACKNOWLEDGMENTS}

We thank Michael Heath, Lewis Mullis, Sara Gremillion, Stephanie Carter, Sean Bertrand, and Allison McKeown for their field assistance, and Benjamin G. Mullinix for statistical advice. This research was supported in part by the Georgia Peanut Commission and the National Peanut Board.

\section{LITERATURE CITED}

1. Baysinger, J. A., Melouk, H. A., and Murray, D. S. 1999. Effects of postemergence herbicides on Cercospora arachidicola Hori and early leaf spot of peanut. Peanut Sci. 26:4-8.

2. Berner, D. K., Berggren, G. T., and Snow, J. P. 1991. Effects of glyphosate on Calonectria crotalariae and red crown rot of soybean. Plant Dis. 75:809-813.

3. Cantonwine, E. G., Culbreath, A. K., and Stevenson, K. L. 2007. Characterization of early leaf spot suppression by strip-tillage in peanut. Phytopathology 97:187-194.

4. Cantonwine, E. G., Culbreath, A. K., Stevenson, K. L., Kemerait, R. C., Jr., Brenneman, T. B., Smith, N. B., and Mullinix, B. G., Jr. 2006. Integrated disease management of leaf spot and spotted wilt of peanut. Plant Dis. 90:493-500.

5. Chiteka, Z. A., Gorbet, D. W., Shokes, F. M., Kucharek, T. A., and Knauft, D. A. 1988. Components of resistance to late leaf spot in peanut I. Levels of variability-implications for selection. Peanut Sci. 15:25-30.

6. Everts, K. L. 2002. Reduced fungicide applications and host resistance for managing three diseases in pumpkin grown on a no-till cover crop. Plant Dis. 86:1134-1141.

7. Harris, D., and Grossbard, E. 1979. Effects of herbicides Gramoxone W and Roundup on Septoria nodorum. Trans. Br. Mycol. Soc. 73:27-33.

8. Lupwayi, N. Z., Clayton, G. W., O'Donovan, J. T., Harker, K. N., Turkington, T. K., and Rice, W. A. 2004. Soil microbiological properties during decomposition of crop residues under conventional and zero tillage. Can. J. Soil Sci. 84:411-419.

9. Madden, L. V. 1992. Rainfall and the dispersal of fungal spores. Adv. Plant Pathol. 8:39-79.

10. Madden, L. V. 1997. Effects of rain on splash dispersal of fungal pathogens. Can. J. Plant Pathol. 19:225-230.

11. Madden, L. V., and Ellis, M. A. 1990. Effects of ground cover on splash dispersal of Phytophthora cactorum from strawberry fruits. J. Phytopathol. 129:170-174.

12. Monfort, W. S. 2002. Effects of reduced tillage, cultivar susceptibility, and reduced fungicide programs on leaf spot of peanut (Arachis hypogaea L.). M.S. thesis. University of Georgia, Athens.

13. Monfort, W. S., Culbreath, A. K., Stevenson, K. L., Brenneman, T. B., Gorbet, D. W., and Phatak, S. C. 2004. Effects of reduced tillage, resistant cultivars, and reduced fungicide inputs on progress of early leaf spot of peanut (Arachis hypogaea). Plant Dis. 88:858-864.

14. Ntahimpera, N., Ellis, M. A., Wilson, L. L., and Madden, L. V. 1998. Effects of a cover crop on splash dispersal of Colletotrichum actatum conidia. Phytopathology 88:536-543.

15. Porter, D. M., and Wright, F. S. 1991. Early leaf spot of peanuts: Effect of conservational tillage practices on disease development. Peanut Sci. 18:76-79.

16. Ristaino, J. B., Parra, G., and Campbell, C. L. 1997. Suppression of Phytophthora blight in bell pepper by a no-till wheat cover crop. Phytopathology 87:242-249.

17. Shaner, G., and Finney, R. E. 1977. The effect of nitrogen fertilization on the expression of slow-mildewing resistance in Knox wheat. Phytopathology 67:1051-1056.

18. Sharma, U., Pfender, W. F., and Adee, E. A. 1989. Effect of glyphosate herbicide on pseudothecia formation by Pyrenophora triticirepentis in infested wheat straw. Plant Dis. 73:647-650.

19. Shokes, F. M., and Culbreath, A. K. 1997. Early and late leaf spots. Pages 17-20 in: Compendium of Peanut Diseases, 2nd ed. N Kokalis-Burelle, D. M. Porter, R. RodriguezKabana, D. H. Smith, and P. Subrahmanyam, eds. American Phytopathological Society, St. Paul, MN.

20. Toubia-Rahme, H., Albertini, L., Barrault, G., and Ali-Haimoud, D. E. 1995. Inhibition of Drechslera teres sclerotioid formation in barley straw by application of glyphosate or paraquat. Plant Dis. 79:595-598.

21. Wu, H., Pratley, J., Lemerle, D., and Haig, T. 2001. Allelopathy in wheat (Triticum aestivum). Ann. Appl. Biol. 139:1-9.

22. Yang, X., and Madden, L. V. 1993. Effect of ground cover, rain intensity and strawberry plants on splash of simulated raindrops. Agric. For. Meteorol. 65:1-20.

23. Yang, X., Wilson, L. L., Madden, L. V., and Ellis, M. A. 1990. Effects of surface topography and rain splash dispersal of Colletotrichum acutatum. Phytopathology 80:1115-1120. 